DOI 10.15290/cnisk.2020.01.08.03

JOANNA MORAWSKA

https://orcid.org/0000-0003-3730-7623

Uniwersytet Szczeciński

\title{
Macierzyństwo w świetle poznańskich czasopism dla kobiet na przełomie XIX i XX wieku - stan badań i perspektywy badawcze ${ }^{1}$
}

\begin{abstract}
Streszczenie
Przemiany cywilizacyjne przełomu XIX i XX w. wpłynęły na zmianę pojmowania roli macierzyństwa i matek w społeczeństwie. Zagadnienia te stały się przedmiotem zainteresowania wielu badaczy, również w Polsce. W odniesieniu do zaboru pruskiego brakuje jednak prac, które omawiaja tę tematykę. Ponadto powstałe na ten temat prace nie uwzględniaja spojrzenia (lub uwzględniaja je tylko w niewielkim stopniu) samych kobiet, w tym wypadku Wielkopolanek, na role i zadania, jakie sa im społecznie przypisywane. Artykuł ma na celu przedstawienie aktualnego stanu badań oraz formułuje listę problemów i zadań badawczych, które należałoby podjaćc, aby uzupełnić stan wiedzy na temat pojmowania kobiecości i macierzyństwa przez mieszkanki Poznańskiego.
\end{abstract}

Słowa kluczowe: macierzyństwo, zabór pruski, polskie czasopisma dla kobiet

1 Publikacja przygotowana/finansowana w ramach programu Ministra Nauki i Szkolnictwa Wyższego pod nazwa DIALOG w latach 2019-2021. Jest wynikiem udziału w projekcie badawczym pt. „Ośrodek badań historii kobiet”, nr 0016/DLG/2019/10. 


\title{
THE MODEL OF MOTHERHOOD FROM THE TURN OF THE 19TH AND 2OTH CENTURIES IN POLISH WOMEN'S MAGAZINES - CURRENT STATUS AND PERSPECTIVES OF RESEARCH
}

\begin{abstract}
Civilization changes from the turn of the 19th and 20th centuries had major impact on roles and duties of motherhood and mothers in society. Many scientists, including Polish researchers, were interested on this subject. In the scope of Prussian Partition there is a lack of elaboration covering this topic. In addition, the resulting papers do not include (or only include to a small extent) the view of women themselves, in this case the Wielkopolska's women, on the roles and tasks that are socially assigned to them. The article aims to present the current state of research and formulates a list of research problems and tasks that should be undertaken to cover the state of knowledge about the concept of femininity and motherhood by the residents in Posen.
\end{abstract}

Keywords: motherhood, Prussian partition, Polish women's magazines

\section{Wprowadzenie}

Przełom XIX i XX w. to czas, kiedy zostaja przedefiniowane zadania matki i jej znaczenie dla społeczeństwa i państwa. Wraz ze stopniowa poprawą warunków życia oraz rozwojem medycyny spadała umieralność niemowląt i kobiet w okresie okołoporodowym oraz wydłużała się średnia długość życia. W efekcie opisywane zjawiska zmieniły cała strukturę społeczna, co łączyć należy z modernizacja społeczeństwa i z tzw. przejściem demograficznym. Gdy umieralność niemowląt znacznie spadła, obniżyła się również dzietność kobiet, zwłaszcza tych z najwyższych warstw społecznych.

Jednym $z$ efektów powyżej opisywanych zmian była ogólnoeuropejska dyskusja dotyczaca odpowiedzialności kobiet za kondycję majacych się urodzić dzieci. Starano się również odpowiedzieć w niej na pytanie o rolę macierzyństwa oraz określić jego znaczenie w sferze prywatnej i publicznej. Korzenie debaty sięgaja drugiej połowy XVIII w., kiedy to została ona zapoczatkowana przez oświeceniowych pedagogów. Przełomowe znaczenie dla pojmowania istoty macierzyństwa miały poglądy Jana Jakuba Rousseau, Johanna Heinricha Pestalozziego oraz Friedricha Wilhelma 
Augusta Froebla ${ }^{2}$. Poza dyskursem pedagogicznym kwestia macierzyństwa pojawiała się także w dyskursie medycznym, a od połowy XIX wieku w debacie na temat umieralności niemowlatt i poprawy higieny życia. Podejmowano ja również w kontekście kwestii robotniczej (sytuacja matek robotnic), a także w dyskursie emancypacyjnym. W efekcie dostrzeżenie negatywnych skutków przemian cywilizacyjnych wprowadziło macierzyństwo w krag zainteresowań państwa. Omawiana debata toczyła się zarówno na łamach prasy i publikacji naukowych, jak i w stowarzyszeniach oraz organizacjach społecznych. Za przyczynę konieczności podjęcia tej tematyki podawano kryzys moralny, zdrowotny i obyczajowy. Podnoszono, że to od wartości rodziny, jako podstawowej komórki społecznej, zależy pomyś1ność społeczeństwa i narodu. Postępujący spadek przyrostu naturalnego doprowadził do konieczności zadbania o „lepsza jakość” rodzonych dzieci, zwłaszcza że największą dzietność notowano wśród żyjących w trudnych warunkach rodzin robotniczych. Obawiano się, że w konsekwencji doprowadzi to do wymierania elity społeczeństwa i degeneracji narodu. Owa troska stała się podstawa eugeniki niemieckiej. Koncepcja ta narodziła się pod koniec XIX w. pod wpływem popularnego wówczas darwinizmu społecznego i miała odnowić biologicznie naród niemiecki.

W obawie przed wspomnianym zepsuciem ludności starano się więc wskazać kobietom właściwą drogę postępowania. Uważano, zgodnie $z$ esencjalnym pojmowaniem płci, że muszą one podporządkować się biologicznemu przeznaczeniu do macierzyństwa. Dzięki „kobiecej naturze" zostały one wyposażone w szereg cech, jak chociażby opiekuńczość, rozwinięta empatia czy wrażliwość, które sprawiały, że naturalna rola każdej kobiety było bycie matką oraz opiekunką domu. Założenia zgodne sa $z$ paradygmatem maternalnym, co oznacza, że to właśnie bycie matka definiuje kobietę. Dodatkowo zgodnie $z$ porzadkiem płci (gender order) wypełnianie biologicznych powinności przez kobiety, czyli samo macierzyństwo, wyznaczało pole ich działań.

\footnotetext{
2 Zob. Edyta Bartkowiak, „Obraz matki i macierzyństwa w obrazach źródłowych $z$ historii wychowania”, Wychowanie w rodzinie, nr 12, 2015, 271-294; Malwina Bednarek, „Macierzyństwo: błogosławieństwo czy przekleństwo - wprowadzenie do dyskursu feministycznego", w: Monika Kocot, Kamil Szafraniec (red.), Języki (pop)kultury w literaturze, mediach i filmie, (Łódź: Wydawnictwo Uniwersytetu Łódzkiego, 2015), 119-127; Bogusława Budrowska, Macierzyństwo jako punkt zwrotny kobiety, (Wrocław: Wydawnictwo Funna, 2000); Daria Łamejko, „Macierzyństwo jako wartość filozoficzna i moralna”, Etyka, nr 36, 2003, 193-208; Anna Józefowicz, „Społeczno-kulturowe wyobrażenia o macierzyństwie w retrospekcji historycznej i współcześnie a rekonesans badawczy", Ars Inter Culturas, vol. 6, 2017, 91-112;
} 


\section{Stan badań}

Przedstawione zagadnienia stały się przedmiotem zainteresowania wielu badaczy. W odniesieniu do perspektywy polskiej można je podzielić na kilka grup tematycznych. Pierwsza $z$ nich to ta dotyczaca badań nad rodzina. Jednym $z$ najistotniejszych zjawisk kultury życia codziennego jest problematyka życia rodzinnego. W jej ramach szczególnego znaczenia nabiera macierzyństwo, bowiem jest wszechobecne w każdej kulturze, ale równocześnie kreuje obraz stosunków międzyludzkich $\mathrm{w}$ obrębie całego społeczeństwa. Badania nad życiem rodzinnym stanowiły przedmiot zainteresowań historyków zachodnioeuropejskich od dawna ${ }^{3}$, jednak przedstawiane wyniki badań nie obejmowały ziem polskich. W pracach polskich historyków problematyka roli rodziny, ze szczególnym uwzględnieniem XVIII, XIX i XX w., zyskała popularność w latach 90. XX w. Historycy i pedagodzy poświęcili uwage modelowi życia rodzinnego oraz roli matki w procesie wychowania dziecka ${ }^{4}$. Duże znaczenie dla rekonstrukcji modelu rodziny miały również badania pod kierunkiem Anny Żarnowskiej i Andrzeja Szwarca, które przedstawiały

3 Zob. Philippe Aries, Historia dziecinstwa. Dziecko i rodzina $w$ dawnych czasach, (Gdańsk: Wydawnictwo Marabut, 1995); Lloyd de Mause, The History of Childhood. The Evolution of Parent-Child Relationships as a Factor in History, (London: Cambridge University Press, 1974); Elisabeth Badinter, Historia miłości macierzyńskiej, (Warszawa: Oficyna Wydawnicza Volumen, 1988); Jean Louise Flandrin, Historia rodziny, (Warszawa: Wydawnictwo Aletheia, 1998); Philippe Aries, Georges Duby (red.), Historia życia prywatnego, t. 1-5, (Wrocław: Wydawnictwo Ossolineum, 1999).

4 Zob. np.: Krzysztof Jakubiak, Adam Winiarz (red.), Wychowanie w rodzinie polskiej od schyłku XVIII do połowy XX wieku, (Bydgoszcz: Wydawnictwo Uczelniane Wyższej Szkoły Pedagogicznej, 2000); Krzysztof Jakubiak (red.), Partnerka, matka, opiekunka. Status kobiety w dziejach nowożytnych od VI do XX wieku, (Bydgoszcz: Wydawnictwo Uczelniane Wyższej Szkoły Pedagogicznej, 2000); Andrzej Denisiuk, Krzysztof Jakubiak (oprac.), Źródła do dziejów wychowania $w$ rodzinie polskiej $w$ XIX i poczatkach XX wieku, (Bydgoszcz: Akademia Bydgoska im. Kazimierza Wielkiego, 2001); Krzysztof Jakubiak, Wiesław Jamrożek (red.), Dziecko w rodzinie i społeczeństwie. Dzieje nowożytne, (Bydgoszcz: Akademia Bydgoska im. Kazimierza Wielkiego, 2002); Dobrochna Kałwa, Adam Walaszek, Anna Żarnowska (red.), Rodzina - prywatność - intymność. Dzieje rodziny polskiej w kontekście europejskim, (Warszawa: Wydawnictwo DiG, 2005); Aneta Bołdyrew, Matka i dziecko w rodzinie polskiej. Ewolucja modelu życia rodzinnego w latach 1795-1918, (Warszawa: Wydawnictwo Neriton, 2008); Wiesława Korzeniowska, Urszula Szuścik (red.), Rodzina. Historia i współczesność. Studium monograficzne, (Kraków: Oficyna Wydawnicza „Impuls”, 2010); Stefania Walasek, Leszek Albański (red.), Wychowanie w rodzinie. Przekaz tradycji i kultury na przestrzeni wieków, t. 1 i 2, (Jelenia Góra: Wydział Nauk Humanistycznych i Społecznych Karkonoskiej Państwowej Szkoły Wyższej, 2011); Stefania Walasek, Anna Haratyk (red.), Wychowanie w rodzinie. Rodzina w Europie na przełomie XIX $i$ XX wieku, t. 12, (Wrocław: Wydawnictwo Petrus, 2016). 
pozycję kobiet w społeczeństwie w XIX i XX w. ${ }^{5}$ Nie mniej istotne sa badania, które poruszały zagadnienia zwiąane $z$ kwestia kobieca. Zrozumienie znaczenia samego terminu wyjaśnia praca Roberta Blobauma ${ }^{6}$, a badania Moniki Nawrot, Nerine Stegmann, Katarzyny Dormus, Adama Winiarza i Łucji Kabzińskiej moga zostać wykorzystane do rekonstrukcji postulowanego wzorca tzw. Matki Polki ${ }^{7}$. W odniesieniu do tematu artykułu należy jednak zaznaczyć, że chociaż wymienione prace maja istotne znaczenie dla omawianej problematyki, jednak tylko w niewielkim stopniu odnoszą się do Poznańskiego. Obszar ten zresztą pod względem badań nad tzw. kwestia kobiecą w porównaniu z Królestwem Polskim i Galicja jest poważnie zaniedbany. Powstałe na ten temat prace nie uwzględniają spojrzenia (lub uwzględniają je tylko w niewielkim stopniu) samych kobiet, w tym wypadku Wielkopolanek, na role i zadania, jakie

5 Zob. Anna Żarnowska, Andrzej Szwarc (red.), Kobieta i społeczeństwo na ziemiach polskich w XIX wieku. Zbiór studiów, (Warszawa: Wydawnictwo DiG, 1995); eidem (red.), Kobieta i edukacja na ziemiach polskich w XIX i XX wieku, cz. 1, (Warszawa: Wydawnictwo DiG, 1992), cz. 2, (Warszawa: Wydawnictwo DiG, 1995); eidem (red.), Kobieta $i$ kultura życia codziennego. Wiek XIX i XX, (Warszawa: Wydawnictwo DiG, 1997); eidem (red.), Kobieta i kultura czasu wolnego. Zbiór studiów, (Warszawa: Wydawnictwo DiG, 2001); eidem (red.), Kobieta i małżeństwo. Społeczno-kulturowe aspekty seksualności. Wiek XIX i XX. Zbiór studiów, (Warszawa: Wydawnictwo DiG), 2004.

6 Cecylia Walewska, Ruch kobiecy $w$ Polsce, cz. 2, (Warszawa: Wydawnictwo Jubileuszowe im. Orzeszkowej, 1909); Agnieszka Baszko, „Organizowanie się kobiet polskich w Poznańskiem na przełomie XIX i XX wieku”, w: Agnieszka Janiak-Jasińska, Katarzyna Sierakowska, Andrzej Szwarc (red.), Działaczki społeczne, feministki, obywatelki... Samoorganizowanie sie kobiet na ziemiach polskich do 1918 roku (na tle porównawczym), (Warszawa: Wydawnictwo Neriton, 2008), 287-306; Grażyna Wyder, „Wielkopolskie działaczki w ruchu narodowo-demokratycznym na terenie Poznańskiego na przełomie XIX i XX wieku. Szkic do działalności politycznej kobiet", Czasopismo Naukowe Instytutu Studiów Kobiecych, t. 1(2), 2017, 48-72; Robert Blobaum, "Kwestia kobieca” w Królestwie Polskim”, w: Agnieszka Janiak-Jasińska, Katarzyna Sierakowska, Andrzej Szwarc (red.), Działaczki społeczne, 37-56.

7 Monika Nawrot, „Wartości i tradycje narodowe w nauczaniu domowym w Wielkopolsce w drugiej połowie XIX i na początkach XX wieku w świetle ówczesnej prasy", w: Elwira J. Kryńska (red.), Ideały wychowania i wzory osobowe narodu polskiego w XIX i XX wieku, (Białystok: Wydawnictwo Trans Humana, 2006), 145-163; Krzysztof Jakubiak, Monika Nawrot-Borowska, „Rodzina polska w XIX wieku jako środowisko wychowawcze i jej funkcja edukacyjna”, Studia Paedagogica Ignatiana, t. 19, nr 2, 2016, 15-46; Katarzyna Dormus, „U progu społecznej dyskusji o macierzyństwie świadomym na ziemiach polskich przełomu XIX i XX wieku", Wychowanie w Rodzinie, t. 12(2), 2015, 255-270; Adam Winiarz, „Wpływ kobiety - matki na życie polskiej rodziny ziemiańskiej doby niewoli narodowej”, w: Krzysztof Jakubiak (red.), Partnerka, matka; Łucja Kabzińska, „Rola i zadania kobiety - matki w twórczości pedagogicznej Królestwa Polskiego przełomu XIX i XX wieku", Zeszyty Naukowe Wyższej Szkoły Pedagogicznej w Bydgoszczy, z. 34, 1998, 113-130. 
sa im społecznie przypisywane ${ }^{8}$. W tych okolicznościach podjęcie tej tematyki przez historyków może stanowić istotne uzupełnienie dotychczasowego stanu badań.

Druga grupę publikacji stanowia prace dotyczace dziejów Prus i Niemiec przełomu XIX i XX w. Wymienić należy zarówno syntezy z zakresu historii społecznej, pióra Stanisława Salmonowicza, Andreasa Gestricha czy Thomasa Nipperdaya ${ }^{9}$, jak i pracę Nicol Matzner-Vogel, która przedstawiła uwarunkowania społeczno-polityczne ochrony macierzyństwa w latach 1905-192910.

Kolejna grupę stanowi literatura dotycząca dziejów Wielkopolski i Poznania pod zaborem pruskim ${ }^{11}$, w tym obozu narodowego ${ }^{12}$. Przytoczyć należy również wiele prac, które poruszają zagadnienia związane

8 Zob. Agnieszka Baszko, „Organizowanie się kobiet polskich w Poznańskiem na przełomie XIX i XX wieku”, w: Agnieszka Janiak-Jasińska, Katarzyna Sierakowska, Andrzej Szwarc (red.), Działaczki społeczne; Grażyna Wyder, „Działalność edukacyjna kobiet-Polek w Wielkim Księstwie Poznańskim w drugiej połowie XIX wieku jako czynnik kształtowania świadomości narodowej”, Rocznik Lubuski, t. 35, 2009, z. 1; eadem, „Towarzystwo Pomocy Naukowej dla dziewcząt polskich w Wielkim Księstwie Poznańskim w latach 1871-1918”, w: Agnieszka Janiak-Jasińska, Katarzyna Sierakowska, Andrzej Szwarc (red.), Działaczki społeczne; eadem, „Wielkopolskie działaczki w ruchu narodowo-demokratycznym na terenie Poznańskiego na przełomie XIX i XX wieku. Szkic do działalności politycznej kobiet", Czasopismo Naukowe Instytutu Studiów Kobiecych, t. 1(2), 2017, 48-72; eadem, „Z dziejów walki o tożsamość narodową - tajne stowarzyszenie kobiet "Warta»", w: Grażyna Wyder, Tomasz Nodzyński (red.), Polacy - Niemcy - Pogranicze. Studia Historyczne, (Zielona Góra: Oficyna Wydawnicza Uniwersytetu Zielonogórskiego, 2006); eadem, „Żeński ruch skautowski w Poznańskiem w relacjach jego organizatorek i uczestniczek w latach 1912-1918", Studia Zachodnie, t. 1, 2011, 165-182.

9 Thomas Nipperdey, Deutsche Geschichte 1866-1918, Bd. 1: Arbeitswelt und Bürgergeist, (München: C.H. Beck, 1990); Andreas Gestrich, Geschichte der Familie im 19. und 20. Jahrhundert, (München: Oldenbourg, 1999).

10 Nicol Matzner-Vogel, Zwischen Produktion und Reproduktion. Die Diskussion über Mutterschaft und Mutterschutz im späten Kaiserreich und der Weimarer Republik (1905-1929), (Frankfurt/M: Peter Lang, 2006).

${ }_{11}$ Zob. Witold Jakóbczyk, Studia nad dziejami Wielkopolski, t. 3: 1890-1914, (Poznań: Wydawnictwo Poznańskie Towarzystwo Przyjaciół Nauk, 1967); Jerzy Kozłowski, Wielkopolska pod zaborem pruskim, (Poznań: Wydawnictwo Poznańskie, 2006).

${ }_{12}$ Henryk Lisiak, „Narodowa Demokracja w dobie Wielkiego Księstwa Poznańskiego. Początki i rozwój 1900-1914", Poznańskie Zeszyty Humanistyczne, t. 4, 2005, 35-46; idem, Narodowa Demokracja w Wielkopolsce w latach 1918-1939, (Poznań: Wydawnictwo Poznańskie, 2006); Jerzy Marczewski, Narodowa Demokracja w Poznańskiem 1900-1914, (Warszawa: Państwowe Wydawnictwo Naukowe, 1967); Roman Wapiński, Narodowa Demokracja 1893-1939. Ze studiów nad dziejami myśli nacjonalistycznej, (Wrocław-Warszawa-Gdańsk: Zakład Narodowy im. Ossolińskich, 1980); Adam Wątor, Narodowa Demokracja w Galicji do 1918 roku, (Szczecin: Wydawnictwo Naukowe US, 2002). 
z rolą i miejscem kobiety $\mathrm{w}$ rodzinie i społeczeństwie na terenie Wielkopolski ${ }^{13}$.

Wreszcie o znaczeniu prasy w badaniach historyczno-pedagogicznych pisali m.in. Jan Hellwig, Zofia Lewartowska i Alicja Kicowska ${ }^{14}$. Andrzej Notkowski omówił specyfikę prasy prowincjonalnej ${ }^{15}$. W stanie badań ująć należy również prace omawiajace znaczenie prasy na terenie zaboru pruskiego, w tym przede wszystkim prace autorstwa Witolda Jakóbczyka i Jerzego Łojka ${ }^{16}$. W dotychczasowej historiografii brakuje jednak prac analitycznych omawiajacych czasopisma dla kobiet w Poznańskiem, w przeciwieństwie do tego typu periodyków wydawanych

13 Zob. Joachim Benyskiewicz, „Rola rodziny w zachowaniu narodowości w warunkach zaboru", w: Stanisław Kubiak, Lech Trzeciakowski (red.), Rola Wielkopolski $w$ dziejach narodu polskiego, (Poznań: Wydawnictwo Naukowe UAM, 1979), 173-167; Monika Abram, „Problem wykształcenia kobiet w publicystyce poznańskiej XIX wieku. Studium porównawcze”, w: Jolanta Miluska, Elżbieta Pakszys (red.), Studia kobiece z psychologii, filozofii $i$ historii, (Poznań: Wydawnictwo Naukowe UAM, 1995), 169-177; Katarzyna Szafer, „Matka - opiekunka - społecznik. Rola kobiety w Wielkim Księstwie Poznańskim na przełomie XIX i XX wieku”, w: Partnerka, matka, 109-120; Monika Nawrot-Borkowska, „Problematyka wychowania na łamach "Dwutygodnika dla Kobiet" (1880-1885)", w: Iwonna Michalska, Grzegorz Michalski (red.), Addenda do dziejów oświaty. $Z$ badań nad prasa XIX i początków XX wieku, (Łódź: Wydawnictwo Uniwersytetu Lódzkiego, 2013), 187-212; Patrycja Kanafocka, Polki w zaborze pruskim 1793-1918. Dwie przestrzenie edukacyjne: publiczna i prywatna, (Opalenica: Wydawnictwo Opalgraf, 2014); Agnieszka Szudarek, „Kwestia narodowa i kwestia kobieca. Zadania Wielkopolanek w obliczu polityki germanizacyjnej w 1908 r. w opinii warszawskich czasopism dla kobiet”, w: Małgorzata Dajnowicz, Adam Miodowski (red.), Polityka i politycy w prasie XX $i$ XXI wieku: polityka w prasie kobiecej, (Białystok: Wydawnictwo Uniwersytetu w Białymstoku, 2019), 15-32.

14 Jan Hellwig, „Czasopiśmiennictwo polskie okresu zaborów jako źródło do badań nad rolą rodziny w wychowaniu (na przykładzie zaboru pruskiego)”, w: Juliusz Jundziłł (red.), Wychowanie $w$ rodzinie od starożytności po wiek XX, (Bydgoszcz: Wydawnictwo Uczelniane WSP, 1994), 267-272; Zofia Lewartowska, „Prasa kobieca i rodzinna”, Zeszyty Prasoznawcze, R. XVI, nr 4, 1975, 5-12; Alicja Kicowska, „Prasa jako źródło w badaniach historyczno-edukacyjnych (wybrane problemy)”, w: Tadeusz Jałmużna, Iwonna Michalska, Grzegorz Michalski (red.), Konteksty i problemy w badaniach historyczno-pedagogicznych, (Kraków: Wydawnictwo „Impuls” 2004), 193-200.

${ }_{15}$ Zob. Andrzej Notkowski, „Infrastruktura materialno-techniczna polskiej prasy prowincjonalnej 1864-1914”, w: Mieczysław Adamczyk, Andrzej Notkowski (red.), Rozwój prowincji naszej: życie społeczno-kulturalne ośrodków lokalnych ziem polskich $w$ dobie popowstaniowej 1864-1914, (Kielce: IBiIN WSP; Warszawa: IBL PAN, 1993), 34-50; idem „Polska prasa prowincjonalna doby popowstaniowej (1865-1918). Jej funkcje społeczne i "geografia" wydawnicza", w: Ryszarda Czepulis-Rastenis (red.), Inteligencja polska XIX i XX wieku. Studia, t. 6, (Warszawa: Wydawnictwo Naukowe PWN, 1991), 185-228.

16 Witold Jakóbczyk, „Prasa w Wielkopolsce (1859-1918)”, w: Jerzy Łojek (red.), Prasa polska 1864-1918, t. 2, (Warszawa: Państwowe Wydawnictwo Naukowe, 1976), 202-214; Jerzy Łojek, Jerzy Myśliński, Wiesław Władyka, Dzieje prasy polskiej, (Warszawa: Wydawnictwo Interpress, 1988). 
w Królestwie Polskim, które maja już wcale niemała literaturę ${ }^{17}$. Badania nad dziejami prasy polskiej w Poznańskiem nie cieszą się zainteresowaniem, chociaż kilka tytułów ma już swoje monografie ${ }^{18}$.

Do omówienia wskazanego zagadnienia wykorzystać należy zarówno czasopisma kobiece, jak i te skierowane do kobiet. Rozróżnienie tych dwóch pojęć jest konieczne do zrozumienia charakteru wykorzystywanych źródeł. Często pojęcia te stosowane sa zamiennie, co rozmywa ich prawdziwy charakter. „Prasa kobieca” rozumiana będzie jako czasopisma kobiece ( $z$ uwzględnieniem twórcy, czyli wydawcy, redaktora czy dziennikarzy), które kształtowały gusty czytelniczek i ich zainteresowania. Natomiast pojęciem „czasopisma dla kobiet” będą określane te periodyki, które wydawane były przede wszystkim przez mężczyzn, którzy narzucali czytelniczkom swój punkt widzenia oraz wyobrażenie, jaka ma być kobieta. Upowszechniały więc treści ważne $z$ punktu widzenia redakcji, nie starając się jednak o nawiązanie kontaktu z czytelniczkami poprzez współredagowanie czasopisma.

Za podstawę źródłową omawianego tematu uznać należy wszystkie poznańskie czasopisma dla kobiet ukazujące się na przełomie XIX i XX w., takie jak: „Dwutygodnik dla Kobiet: Pismo Belletrystyczne i Naukowe” (1880-1885) (przekształcony później w „Tygodnik Beletrystyczny i Naukowy”, a następnie w „Dom Polski. Czasopismo Beletrystyczne i Naukowe”19), „Głos Wielkopolanek. Tygodnik Społeczno-Narodowy dla Kobiet Wszystkich Stanów” oraz „Gazeta dla Kobiet. Dwutygodnik Poświęcony Sprawom Kobiet Pracujacych” (1909-1914). Pierwsze dwa tytuły wydawane były przez kobiety, ostatni zaś przez księży katolickich. Warto zaznaczyć, że od 1909 r. wydawane było przez Helenę Rzepecką także czasopismo „Zjednoczenie”, organ Zjednoczenia Towarzystw Kobiecych Oświatowych na Rzeszę Niemiecką. Do czasów współczesnych zachowało się jednak jedynie kilka egzemplarzy.

17 Zob. Jerzy Franke, Polska prasa kobieca w latach 1820-1918. W kręgu ofiary i poświęcenia, (Warszawa: Wydawnictwo SBP, 1999); idem, „Problemy polityki literackiej warszawskich czasopism kobiecych w latach 1905-1918”, Kwartalnik Historii Prasy Polskiej, t. 27, nr 2, 1988; idem, Wokół buntu i pokory: warszawskie czasopisma kobiece w latach 1905-1918, (Warszawa: IINiSB UW, 2000).

18 Zob. Grażyna Gzella, „Twórcy «Lecha. Gazety Gnieźnieńskiej” do 1914 roku”, Studia Medioznawcze, $\mathrm{nr}$ 57/2, 2014, 199-209.

19 „Dom Polski” ukazywał się w latach 1889-1890. 


\section{Perspektywy badawcze}

Biorac pod uwagę stan badań zwiąany $z$ tematyką roli matki i macierzyństwa pod zaborem pruskim, warto prześledzić, jak na łamach poznańskich czasopism dla kobiet $z$ perspektywy Wielkopolanek modelowany był wzorzec matki i macierzyństwa na przełomie XIX i XX w. oraz czy i jak na potrzeby narodowe adaptowane były kwestie nawiazujace do modernizujaccej się koncepcji macierzyństwa. Czy wraz z rozwojem koncepcji „nowoczesnego państwa” i nasileniem się polityki antypolskiej „nowoczesna matka” oznaczać miała dla samych Wielkopolanek kobietę wypełniająca „misję patriotyczna”, postępująca zgodnie $z$ zaleceniami modernizacyjnymi, czy może miała ona łączyć oba te zadania?

W przypadku ziem polskich jednym ze skutków pozbawienia Polaków suwerennego państwa było postawienie przed kobietami zadania wypełnienia „misji patriotycznej”. Podkreślano więc ich rolę jako pierwszych nauczycielek swoich dzieci. Wypełnianie owej misji stało się więc nadrzędnym zadaniem polskich kobiet, zwłaszcza w okresie nasilającej się polityki germanizacyjnej i rusyfikacyjnej.

Wizerunek Matki Polki był więc konstruowany w oparciu o konkretny wzorzec kobiecości. W Poznańskiem, gdzie jako dominująca należy wymienić tradycyjna wizję porządku społecznego, kobietę identyfikowano wyłącznie ze sferą domowa. Ten kierunek narracji góruje w literaturze przedmiotu. Dotąd nie zajęto się jednak recepcją tego wzorca wśród Wielkopolanek $z$ różnych warstw społecznych. Analiza dyskursu na ten temat na łamach prasy kobiecej miałaby na celu oddanie głosu samym mieszkankom Poznańskiego. Pozwoliłoby to podjać próbę określenia, czy rzeczywiście misja patriotyczna narzucona kobietom przez sytuację polityczną oraz koncepcje polityków, działaczy społecznych i Kościół jest tym, z czym Wielkopolanki się identyfikowały. Czy w zwiazku $z$ tym widoczne są różnice w narracji samych kobiet i mężczyzn piszących dla kobiet?

Przełom XIX i XX w. to czas, w którym rozpoczyna się proces modernizowania „matczynej misji patriotycznej” i propagowania obrazu matki świadomej swych zadań. Uważano bowiem, że lepiej wypełni ona swoje obowiąki niż „przypadkowe lub przymusowe matki doby minionej”20. W tych okolicznościach konieczne będzie więc przedstawienie

\footnotetext{
20 Katarzyna Dormus, „U progu społecznej dyskusji o macierzyństwie świadomym na zie-
} miach polskich przełomu XIX i XX wieku”, Wychowanie w Rodzinie, t. 12 (2), 2015, 268. 
XIX-wiecznego wzorca Matki Polki oraz jego ewolucję wymuszona mającymi wówczas miejsce przemianami cywilizacyjnymi. Szczególnie istotna jest kwestia, w jakim stopniu wzorce i wartości postulowane w europejskich dyskursach (dyskurs pedagogiczny, higieniczny, medyczny, demograficzny, emancypacyjny i społeczny) ujawniły się w poznańskiej prasie kobiecej i jak bardzo wpłynęły na postulowany, nowoczesny wzorzec macierzyństwa w Wielkopolsce.

Kluczowa w tym kontekście będzie cezura roku 1908, kiedy to w marcu weszła w życie ustawa wywłaszczeniowa, a dwa miesiące później prawo o stowarzyszeniach wraz z tzw. paragrafem kagańcowym, uniemożliwiającym posługiwanie się językiem polskim na zgromadzeniach publicznych w powiatach, w których Niemcy stanowili więcej niż $40 \%$ mieszkańców ${ }^{21}$. Nowo wprowadzone prawodawstwo polepszyło jednocześnie sytuację niemieckich kobiet, które uzyskały dostęp do wyższej edukacji, a przede wszystkim znosiło obowiąujacy od 1850 r. zakaz przynależności do organizacji politycznych. Owe wydarzenia odnowiły dyskusję na łamach prasy dotycząca powiązan między kwestią kobieca i narodowa oraz koniecznością budowania nowoczesnego narodu pod zaborem. Coraz liczniejsze głosy postulowały konieczność uobywatelnienia wzorca Matki Polki, a zrzeszanie się kobiet miało stanowić obowiazek patriotyczny samych Wielkopolanek. Głoszono też konieczność walki z zaostrzającą się polityką germanizacyjną i niemiecką propaganda nacjonalistyczna, która również w odniesieniu do kobiet propagowała macierzyństwo, ale jako element wzorca kobiety niemieckiej i jej zadań w umacnianiu niemczyzny na tzw. Niemieckim Wschodzie. Bardzo ważnym zadaniem będzie więc poszukiwanie odpowiedzi na pytania, jak te wydarzenia były odebrane przez publicystki piszace na łamach prasy dla kobiet i w jakim zakresie doprowadziły do rekonstrukcji wielkopolskiej wersji Matki Polki.

W dotychczasowej literaturze przedmiotu dominuje poglad o podporządkowaniu zadań matek misji narodowej. Punkt widzenia Wielkopolanek widoczny na łamach prasy dla kobiet nie pozwala na takie jednoznaczne stwierdzenie, sam dyskurs zaś na temat matek i macierzyństwa na łamach prasy kobiecej nie był zdominowany przez „misję narodowa”

${ }^{21}$ Adam Galos, „Lewica mieszczańska a polityka bloku Bülowa (geneza wniesienia do parlamentu niemieckiego projektu ustawy o związkach i zgromadzeniach)", Kwartalnik Historyczny, R. 105, 1998, z. 2, 53-69. 
kobiet. Miała ona raczej charakter postulatywny. Występująca na łamach analizowanych tytułów potrzeba zmian w rozumieniu macierzyństwa i zadań oraz statusu matek wynikała bowiem $z$ ogólnych przemian cywilizacyjnych. W momentach nasilania się polityki antypolskiej oraz wchodzenia w życie kolejnych antypolskich ustaw pewne elementy wizji nowoczesnego macierzyństwa były przez Wielkopolanki reinterpretowane na potrzeby narodowe. Hipoteza ta wymaga jednak dalszych badań.

\section{Podsumowanie}

Biorac pod uwagę brak opracowań zwiąanych $z$ podejmowanym zagadnieniem na terytorium Wielkopolski, prowadzone badania uwzględniające ukazane w artykule perspektywy badawcze mają szansę stać się istotnym uzupełnieniem stanu wiedzy na ten temat. Dzięki temu możliwe będzie lepsze zrozumienie znaczenia kobiecości, a także mieszczącego się w niej macierzyństwa dla Wielkopolanek przełomu XIX i XX w.

\section{Bibliografia}

\section{Opracowania}

Abram, Monika. „Problem wykształcenia kobiet w publicystyce poznańskiej XIX wieku. Studium porównawcze”, w: Jolanta Miluska, Elżbieta Pakszys (red.), Studia kobiece z psychologii, filozofii $i$ historii, (Poznań: Wydawnictwo Naukowe UAM, 1995), 169-178.

Aries, Philippe. Duby, Georges (red.), Historia życia prywatnego, t. 1-5, (Wrocław: Wydawnictwo Ossolineum, 1999).

Aries, Philippe. Historia dziecinstwa. Dziecko i rodzina w dawnych czasach, (Gdańsk: Wydawnictwo Marabut, 1995).

Badinter, Elisabeth. Historia miłości macierzyńskiej, (Warszawa: Oficyna Wydawnicza Volumen, 1988).

Bartkowiak, Edyta. „Obraz matki i macierzyństwa w obrazach źródłowych $z$ historii wychowania”, Wychowanie $w$ Rodzinie, nr 12, 2015, 271-294. Baszko, Agnieszka. „Organizowanie się kobiet polskich w Poznańskiem na przełomie XIX i XX wieku”, w: Agnieszka Janiak-Jasińska, Katarzyna Sierakowska, Andrzej Szwarc (red.), Działaczki społeczne, feministki, obywatelki... Samoorganizowanie sie kobiet na ziemiach polskich do 
1918 roku (na tle porównawczym), (Warszawa: Wydawnictwo Neriton, 2008), 287-306.

Bednarek, Malwina. „Macierzyństwo: błogosławieństwo czy przekleństwo wprowadzenie do dyskursu feministycznego", w: Monika Kocot, Kamil Szafraniec (red.), Języki (pop)kultury w literaturze, mediach i filmie, (Eódź: Wydawnictwo Uniwersytetu Łódzkiego, 2015), 119-127.

Benyskiewicz, Joachim. „Rola rodziny w zachowaniu narodowości w warunkach zaboru", w: Stanisław Kubiak, Lech Trzeciakowski (red.), Rola Wielkopolski w dziejach narodu polskiego, (Poznań: Wydawnictwo Naukowe UAM, 1979), 173-177.

Blobaum, Robert. "Kwestia kobieca” w Królestwie Polskim”, w: Agnieszka Janiak-Jasińska, Katarzyna Sierakowska, Andrzej Szwarc (red.), Działaczki społeczne, feministki, obywatelki... Samoorganizowanie się kobiet na ziemiach polskich do 1918 roku (na tle porównawczym), (Warszawa: Wydawnictwo Neriton, 2008), 37-56.

Bołdyrew, Aneta. Matka i dziecko w rodzinie polskiej. Ewolucja modelu życia rodzinnego w latach 1795-1918, (Warszawa: Wydawnictwo Neriton, 2008).

Budrowska, Bogusława. Macierzyństwo jako punkt zwrotny kobiety, (Wroclaw: Wydawnictwo Funna, 2000).

De Mause, Lloyd. The History of Childhood. The Evolution of Parent-Child Relationships as a Factor in History, (London: Cambridge University Press, 1974).

Denisiuk, Andrzej. Jakubiak, Krzysztof (oprac.), Źródła do dziejów wychowania w rodzinie polskiej w XIX i poczatkach XX wieku, (Bydgoszcz: Akademia Bydgoska im. Kazimierza Wielkiego, 2001).

Dormus, Katarzyna. „U progu społecznej dyskusji o macierzyństwie świadomym na ziemiach polskich przełomu XIX i XX wieku", Wychowanie $w$ Rodzinie, t. 12(2), 2015, 255-270.

Flandrin, Jean-Louis. Historia rodziny, (Warszawa: Wydawnictwo Aletheia, 1998).

Franke, Jerzy. Polska prasa kobieca $w$ latach 1820-1918. W kregu ofiary i poświęcenia, (Warszawa: Wydawnictwo SBP, 1999).

Franke, Jerzy. Wokół buntu i pokory: warszawskie czasopisma kobiece w latach 1905-1918, (Warszawa: IINiSB UW, 2000). 
Franke, Jerzy. „Problemy polityki literackiej warszawskich czasopism kobiecych w latach 1905-1918", Kwartalnik Historii Prasy Polskiej, t. 27, nr 2, 1988.

Galos, Adam. „Lewica mieszczańska a polityka bloku Bülowa (geneza wniesienia do parlamentu niemieckiego projektu ustawy o zwiazkach i zgromadzeniach)", Kwartalnik Historyczny, R. CV, z. 2, 1998, 53-69.

Gestrich, Andreas. Geschichte der Familie im 19. und 20. Jahrhundert, (München: Oldenbourg, 1999).

Gzella, Grażyna. „Twórcy "Lecha. Gazety Gnieźnieńskiej» do 1914 roku”, Studia Medioznawcze, nr 57/2, 2014,199-209.

Hellwig, Jan. „Czasopiśmiennictwo polskie okresu zaborów jako źródło do badań nad rola rodziny w wychowaniu (na przykładzie zaboru pruskiego)", w: Juliusz Jundziłł (red.), Wychowanie $w$ rodzinie od starożytności po wiek XX, (Bydgoszcz: Wydawnictwo Uczelniane WSP, 1994), 267-272. Jakóbczyk, Witold. Studia nad dziejami Wielkopolski, t. 3: 1890-1914, (Poznań: Wydawnictwo Poznańskie Towarzystwo Przyjaciół Nauk, 1967).

Jakóbczyk, Witold. „Prasa w Wielkopolsce (1859-1918)”, w: Jerzy Łojek (red.), Prasa polska 1864-1918, t. 2, (Warszawa: Państwowe Wydawnictwo Naukowe, 1976), 202-214.

Jakubiak, Krzysztof (red.), Partnerka, matka, opiekunka. Status kobiety $w$ dziejach nowożytnych od VI do XX wieku, (Bydgoszcz: Wydawnictwo Uczelniane Wyższej Szkoły Pedagogicznej, 2000).

Jakubiak, Krzysztof. Jamrożek, Wiesław (red.), Dziecko $w$ rodzinie $i$ społeczeństwie. Dzieje nowożytne, (Bydgoszcz: Akademia Bydgoska im. Kazimierza Wielkiego, 2002).

Jakubiak, Krzysztof. Nawrot-Borowska, Monika. „Rodzina polska w XIX wieku jako środowisko wychowawcze i jej funkcja edukacyjna”, Studia Paedagogica Ignatiana, t. 19, nr 2, 2016, 15-46.

Jakubiak, Krzysztof. Winiarz, Adam (red.), Wychowanie $w$ rodzinie polskiej od schyłku XVIII do połowy XX wieku, (Bydgoszcz: Wydawnictwo Uczelniane Wyższej Szkoły Pedagogicznej, 2000).

Józefowicz, Anna. „Społeczno-kulturowe wyobrażenia o macierzyństwie w retrospekcji historycznej i współcześnie a rekonesans badawczy", Ars Inter Culturas, vol. 6, 2017, 91-112. 
Kabzińska, Łucja. „Rola i zadania kobiety - matki w twórczości pedagogicznej Królestwa Polskiego przełomu XIX i XX wieku”, Zeszyty Naukowe Wyższej Szkoły Pedagogicznej w Bydgoszczy, z. 34, 1998, 113-130.

Kałwa, Dobrochna. Walaszek, Adam. Żarnowska, Anna (red.), Rodzina-prywatność - intymność. Dzieje rodziny polskiej w kontekście europejskim, (Warszawa: Wydawnictwo DiG, 2005).

Kanafocka, Patrycja. Polki w zaborze pruskim 1793-1918. Dwie przestrzenie edukacyjne: publiczna i prywatna, (Opalenica: Wydawnictwo Opalgraf, 2014).

Kicowska, Alicja. „Prasa jako źródło w badaniach historyczno-edukacyjnych (wybrane problemy)", w: Tadeusz Jałmużna, Iwonna Michalska, Grzegorz Michalski (red.), Konteksty i problemy $w$ badaniach historyczno-pedagogicznych, (Kraków: Wydawnictwo „Impuls” 2004), 193-200.

Korzeniowska, Wiesława. Szuścik, Urszula (red.), Rodzina. Historia i wspótczesność. Studium monograficzne, (Kraków: Oficyna Wydawnicza „Impuls", 2010).

Kozłowski, Jerzy. Wielkopolska pod zaborem pruskim, (Poznań: Wydawnictwo Poznańskie, 2006).

Lewartowska, Zofia. „Prasa kobieca i rodzinna”, Zeszyty Prasoznawcze, R. XVI, nr 4, 1975, 5-12.

Lisiak, Henryk. „Narodowa Demokracja w dobie Wielkiego Księstwa Poznańskiego. Początki i rozwój 1900-1914”, Poznańskie Zeszyty Humanistyczne, t. 4, 2005, 35-46.

Lisiak, Henryk. Narodowa Demokracja w Wielkopolsce w latach 1918-1939, (Poznań: Wydawnictwo Poznańskie, 2006).

Łamejko, Daria. „Macierzyństwo jako wartość filozoficzna i moralna”, Etyka, nr 36, 2003, 193-208.

Łojek, Jerzy. Myśliński, Jerzy. Władyka, Wiesław. Dzieje prasy polskiej, (Warszawa: Wydawnictwo Interpress, 1988).

Marczewski, Jerzy. Narodowa Demokracja w Poznańskiem 1900-1914, (Warszawa: Państwowe Wydawnictwo Naukowe, 1967).

Matzner-Vogel, Nicol. Zwischen Produktion und Reproduktion. Die Diskussion über Mutterschaft und Mutterschutz im späten Kaiserreich und der Weimarer Republik (1905-1929), (Frankfurt/M: Peter Lang, 2006).

Nawrot, Monika. „Wartości i tradycje narodowe w nauczaniu domowym w Wielkopolsce w drugiej połowie XIX i na poczatkach XX wieku w świetle 
ówczesnej prasy", w: Elwira J. Kryńska (red.), Ideały wychowania i wzory osobowe narodu polskiego w XIX i XX wieku, (Białystok: Wydawnictwo Trans Humana, 2006), 145-163.

Nawrot-Borowska, Monika. „Problematyka wychowania na łamach "Dwutygodnika dla Kobiet" (1880-1885)", w: Iwonna Michalska, Grzegorz Michalski (red.), Addenda do dziejów oświaty. Z badań nad prasa XIX i początków XX wieku, (Łódź: Wydawnictwo Uniwersytetu Lódzkiego, 2013), $187-212$.

Nipperdey, Thomas. Deutsche Geschichte 1866-1918, Teil I: Arbeiwelt und bürgergesit, (München: Wydawncitwo C.H. Beck, 1990).

Notkowski, Andrzej. „Infrastruktura materialno-techniczna polskiej prasy prowincjonalnej 1864-1914", w: Mieczysław Adamczyk, Andrzej Notkowski (red.), Rozwój prowincji naszej: życie społeczno-kulturalne ośrodków lokalnych ziem polskich $w$ dobie popowstaniowej 1864-1914, (Kielce: IBiIN WSP; Warszawa: IBL PAN, 1993), 34-50.

Notkowski, Andrzej. „Polska prasa prowincjonalna doby popowstaniowej (1865-1918). Jej funkcje społeczne i "geografia” wydawnicza”, w: Ryszarda Czepulis-Rastenis (red.), Inteligencja polska XIX i XX wieku. Studia, t. 6, (Warszawa: Wydawnictwo Naukowe PWN, 1991), 185-228.

Szafer, Katarzyna. „Matka - opiekunka - społecznik. Rola kobiety w Wielkim Księstwie Poznańskim na przełomie XIX i XX wieku”, w: Krzysztof Jakubiak (red.), Partnerka, matka, opiekunka. Status kobiety w dziejach nowożytnych od XVI do XX wieku, (Bydgoszcz: Wydawnictwa Uczelniane Wyższej Szkoły Pedagogicznej, 2000), 109-120.

Szudarek, Agnieszka. „Kwestia narodowa i kwestia kobieca. Zadania Wielkopolanek w obliczu polityki germanizacyjnej w $1908 \mathrm{r}$. w opinii warszawskich czasopism dla kobiet", w: Małgorzata Dajnowicz, Adam Miodowski (red.), Polityka i politycy w prasie XX $i$ XXI wieku: polityka w prasie kobiecej, (Białystok: Wydawnictwo Uniwersytetu w Białymstoku, 2019), 15-32.

Walasek, Stefania. Albański, Leszek (red.), Wychowanie w rodzinie. Przekaz tradycji i kultury na przestrzeni wieków, t. 1 i 2, (Jelenia Góra: Wydział Nauk Humanistycznych i Społecznych Karkonoskiej Państwowej Szkoły Wyższej, 2011). 
Walasek, Stefania. Haratyk, Anna (red.), Wychowanie w rodzinie. Rodzina w Europie na przełomie XIX i XX wieku, t. 12, (Wrocław: Wydawnictwo Petrus, 2016).

Walewska, Cecylia. Ruch kobiecy w Polsce, cz. 2, (Warszawa: Wydawnictwo Jubileuszowe im. Orzeszkowej, 1909).

Wapiński, Roman. Narodowa Demokracja 1893-1939. Ze studiów nad dziejami myśli nacjonalistycznej, (Wrocław-Warszawa-Gdańsk: Zakład Narodowy im. Ossolińskich, 1980).

Wattor, Adam. Narodowa Demokracja w Galicji do 1918 roku, (Szczecin: Wydawnictwo Naukowe US, 2002).

Winiarz, Adam. „Wpływ kobiety - matki na życie polskiej rodziny ziemiańskiej doby niewoli narodowej”, w: Krzysztof Jakubiak (red.), Partnerka, matka, opiekunka. Status kobiety $w$ dziejach nowożytnych od XVI do XX wieku, (Bydgoszcz: Wydawnictwa Uczelniane Wyższej Szkoły Pedagogicznej, 2000), 146-156.

Wyder, Grażyna. „Wielkopolskie działaczki w ruchu narodowo-demokratycznym na terenie Poznańskiego na przełomie XIX i XX wieku. Szkic do działalności politycznej kobiet", Czasopismo Naukowe Instytutu Studiów Kobiecych, t. 1(2), 2017, 48-72.

Wyder, Grażyna. „Działalność edukacyjna kobiet-Polek w Wielkim Księstwie Poznańskim w drugiej połowie XIX wieku jako czynnik kształtowania świadomości narodowej”, Rocznik Lubuski, t. 35, z. 1, 2009, 85-100.

Wyder, Grażyna. „Żeński ruch skautowski w Poznańskiem w relacjach jego organizatorek i uczestniczek w latach 1912-1918”, Studia Zachodnie, t. 1, 2011, 165-182.

Wyder, Grażyna. „Towarzystwo Pomocy Naukowej dla dziewcząt polskich w Wielkim Księstwie Poznańskim w latach 1871-1918”, w: Agnieszka Janiak-Jasińska, Katarzyna Sierakowska, Andrzej Szwarc (red.), Działaczki społeczne, feministki, obywatelki... Samoorganizowanie się kobiet na ziemiach polskich do 1918 roku (na tle porównawczym), (Warszawa: Wydawnictwo Neriton, 2008), 307-322.

Wyder, Grażyna. „Z dziejów walki o tożsamość narodowa - tajne stowarzyszenie kobiet "Warta»", w: Grażyna Wyder, Tomasz Nodzyński (red.), Polacy - Niemcy - Pogranicze. Studia Historyczne, (Zielona Góra: Oficyna Wydawnicza Uniwersytetu Zielonogórskiego, 2006), 183-198. 
Żarnowska, Anna. Szwarc, Andrzej (red.), Kobieta i edukacja na ziemiach polskich $w$ XIX $i$ XX wieku, cz. 1, (Warszawa: Wydawnictwo DiG, 1992), cz. 2, (Warszawa: Wydawnictwo DiG, 1995).

Żarnowska, Anna. Szwarc, Andrzej (red.), Kobieta i kultura czasu wolnego. Zbiór studiów, (Warszawa: Wydawnictwo DiG, 2001).

Żarnowska, Anna. Szwarc, Andrzej (red.), Kobieta i kultura życia codziennego. Wiek XIX i XX, (Warszawa: Wydawnictwo DiG, 1997).

Żarnowska, Anna. Szwarc, Andrzej (red.), Kobieta i małżeństwo. Społeczno-kulturowe aspekty seksualności. Wiek XIX i XX. Zbiór studiów, (Warszawa: Wydawnictwo DiG), 2004.

Żarnowska, Anna. Szwarc, Andrzej (red.), Kobieta i spoleczeństwo na ziemiach polskich w XIX wieku. Zbiór studiów, (Warszawa: Wydawnictwo DiG, 1995). 